\title{
ZDOBENÁ KOSTENÁ RUKOVÄŤ Z PUSTÉHO HRADU VO ZVOLENE ${ }^{1}$
}

\author{
Miloš Čierny - Noémi Beljak Pažinová - Ján Beljak
}

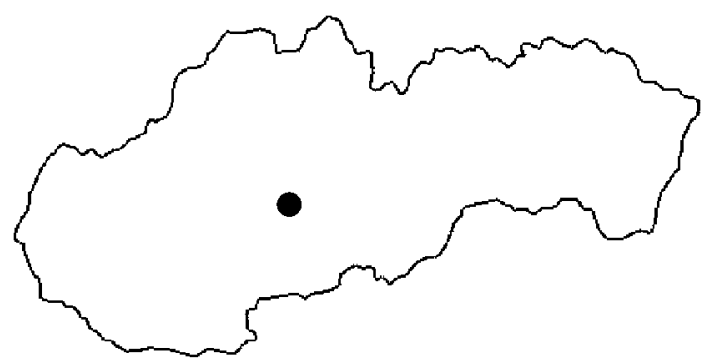

DOI: https://doi.org/10.31577/szausav.2020.67.17

Keywords: Slovakia, Pustý hrad Castle in Zvolen, High Middle Ages $\left(13^{\text {th }} / 14^{\text {th }}\right.$ century), bone handle, relief motif

\section{Decorated bone handle from Pustý hrad (Deserted Castle) in Zvolen}

The presented article presents the unique find of a plastically decorated bone handle from the high medieval Pustý hrad Castle in Zvolen. Its first part was discovered in 1996 during excavations of V. Hanuliak in the interior of the tower in the eastern line of the Upper castle's fortification. The second, smaller, part was found in excavation season 2019 in the moat of the same tower. The aim is to carry out a complex analysis of the artifact with relief decoration and its setting in a wider chronological context. The relief motif on the handle represents a figure of a knight in a helm kneeling before another standing figure (a lady?) with her arms around him, pressing his head against her chest. On the basis of analogies, we interprete the image as a love scene. From the historical point of view, the helm depicted on the knight's head is important; it can be dated to the beginning of the $14^{\text {th }}$ century. The decorated handle is a luxurious item which is an expression of table maners of the castle nobility.

\section{ÚVOD}

Národná kultúrna pamiatka Pustý hrad vo Zvolene (obr. 1) sa rozkladá na dvoch vrcholoch rovnomenného kopca, ktorý sa vypína na juhozápadnom okraji mesta Zvolen v pohorí Javorie nad sútokom Hrona a Slatiny. Stredovekí stavitelia využili prírodné danosti polohy a na vrcholovej plošine (571 m n. m.) postavili Horný hrad (obr. 2) s rozlohou 3,5 ha a nižšie $(476 \mathrm{~m} \mathrm{n}$. m.) umiestnili Dolný hrad s rozlohou 0,7 ha. Spolu s tzv. spojovacou častou tvoria areál s rozlohou 4,7 ha. Vrcholnostredoveké opevnenie dali postavit’ a intenzívne využívali hlavne uhorskí králi z rodu Arpádovcov (Beljak a i. 2014, 36-44). Vznik a počiatky kamenného hradu môžeme spájat’ s utvorením Zvolenského komitátu, rozsiahlej územnosprávnej jednotky, ktorú spravoval králom poverený úradník, župan, sídliaci vo Zvolene. Zvolenský komitát vznikol azda už na začiatku 12. storočia. Najvýraznejšie stavebné aktivity sú v areáli hradu dokumentované od polovice 13. až začiatkom 14. storočia. Hradný areál je definitívne opustený v 15. storočí, stráca funkciu opevnenia, zaniká prevádzka sídla a mení sa miesto královskej rezidencie (Beljak/ Beljak PažinoválŠimkovic 2018).

Záujem o terénny výskum lokality je evidentný od 18. storočia (Beljak/Maliniak/Pažinová 2011). Moderný archeologický výskum, realizovaný každoročne od roku 1992, osvetlil jeho význam ako sídla Zvolenského komitátu, oblúbeného miesta odpočinku a polovačiek panovníkov Uhorska vo vrcholnom stredoveku. Dlhoročný výskum hradu začal archeológ $V$. Hanuliak (1999; 2001; 2006), ktorý svoje bádatelské úsilie sústredil na Horný hrad (podrobne Beljak Pažinová/Beljak 2020). Od sezóny 2009 záštitu nad výskumom hradu prevzal AÚ SAV v Nitre a pod vedením autorov príspevku pokračuje nepretržite dodnes. Centrum záujmu sa sústredil najprv na Dolný hrad (Beljak a i. 2014) avšak postupne sa výskumné aktivity presunuli spät na Horný hrad, kde sa v roku 2015 podarilo komplexne preskúmat’ aj jedinečnú stredovekú cisternu (Beljak/Beljak Pažinová/Šimkovic 2016). Systematický výskum Horného hradu pokračuje plynule od roku 2016 a počas posledných štyroch sezón sa podarilo identifikovat nové

1 Príspevok vznikol s podporou Agentúry na podporu výskumu a vývoja na základe zmluvy APVV-17-0063 „Vita intra muros interdisciplinárny výskum hradov stredného Slovenska“ a ako dopadový ukazovatel’ udržatel’nosti projektu ITMS: 26220120059. 


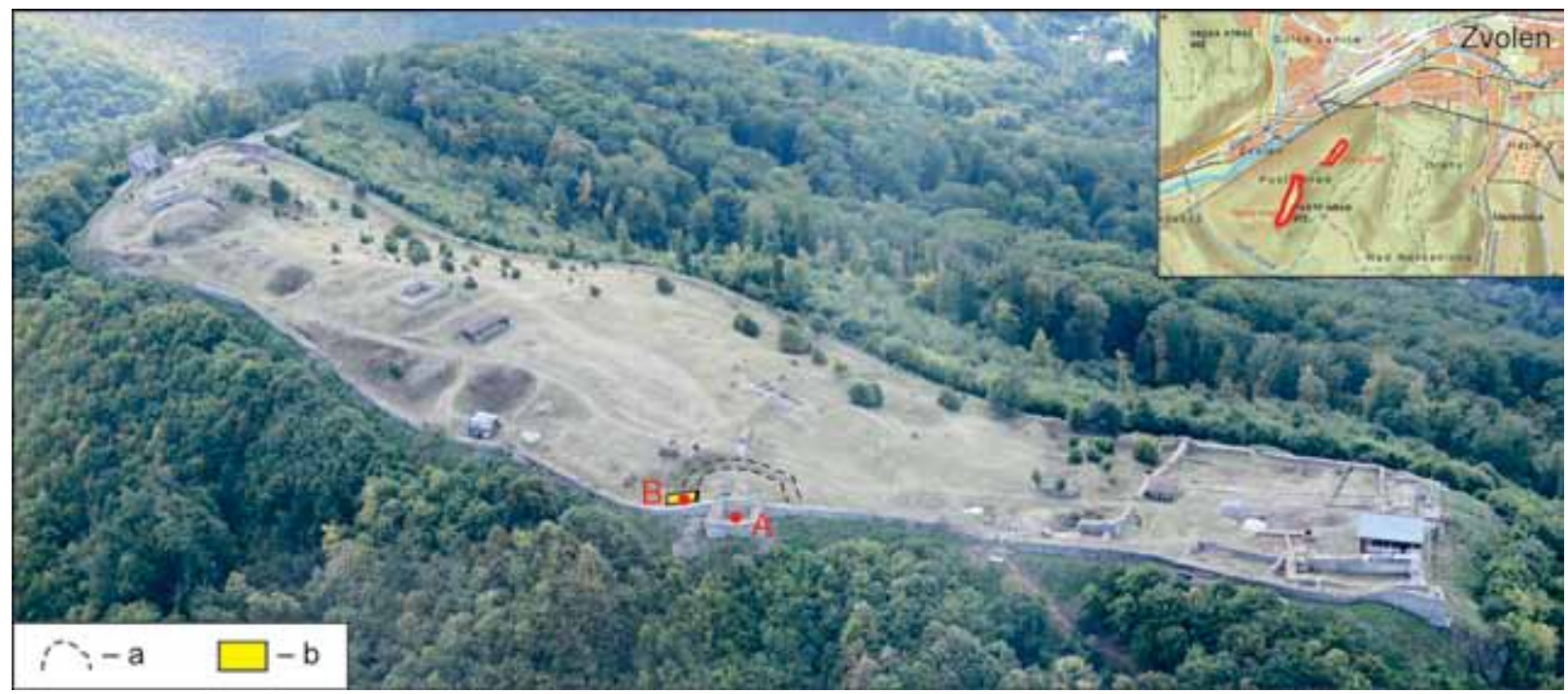

Obr. 1. Zvolen-Pustý hrad, Horný hrad. Letecký pohl’ad na hradný areál z východu. A - miesto nálezu 1. fragmentu v roku 1996; B - miesto nálezu 2. fragmentu v roku 2019. Legenda: a - priekopa veži vo východnej línii opevnenia; b - sonda $4 / 2019$. Autor J. Beljak.

stavebné etapy výstavby hradu a získalo sa množstvo vzácnych artefaktov (bližšie Beljak/Beljak Pažinovál Šimkovic 2015; 2018, 5-63).

V rámci predloženého príspevku predstavíme jedinečný nález plasticky zdobenej kostenej rukoväte objavenej v dvoch častiach (prvá v roku 1996 a druhá v roku 2019) na Hornom Pustom hrade. Presná zhoda oboch artefaktov je doložená v proporciách, rezbe motívu aj v lome. Reliéfny motív rukoväte nemá obdoby v európskom priestore a samotný nález predstavuje luxusný tovar, ktorý rozširuje naše poznatky o materiálnej kultúre šlachtických sídel vrcholného stredoveku nášho územia.

\section{NÁLEZOVÝ KONTEXT A OPIS ARTEFAKTU}

Prvá čast' figurálne zdobenej rukoväte (obr. 3: 1) sa našla v auguste 1996 na Hornom Pustom hrade v interiéri veže vonkajšieho východného opevnenia v híbke 2,1 m (Hanuliak 2001, 189, obr. 3). Fragment mal dížku 7,8 cm, šírku 2,5 cm, hrúbku 1,1 cm a hmotnost’ $13 \mathrm{~g}$. V jeho spodnej časti bol oválny otvor pre násadu tŕňa noža a malej časti čepele.

V septembri 2019 sa podarilo objavit d’alšiu čast' (obr. 3: 2) z rukoväte v híbke 1,2-1,3 m v južnej priekope veži (sonda 4/2019) pri vnútornom líci východnej línie opevnenia (obr. 4). Vzdialenost̉ medzi miestami objavu oboch fragmentov je maximálne $20 \mathrm{~m}$ (obr. 1; 2). Druhá čast’ artefaktu má dížku 3,2 cm, šírku $0,9 \mathrm{~cm}$ a hmotnost' $3 \mathrm{~g}$. Rezba motívu a proporcie nálezu presne nadväzujú na skôr objavenú väčšiu čast̆ artefaktu. Taktiež lom na oboch fragmentoch sa zhoduje a časti do seba presne zapadajú (obr. 3: 3). Novo objavená čast̉ rukoväte predstavuje pokračovanie tela (chrbta) klačiacej postavy scénického zobrazenia. Jediný viditelný rozdiel medzi oboma častami artefaktu je v ich odlišnom sfarbení. Predpokladáme, že ide o prejav rôznej formy deponovania (prvá čast v kultúrnej vrstve interiéru veže a druhá pod sutinovým zásypom priekopy) nálezov i konzerváciou prvého kusu.

\section{ANALÝZA}

\section{Surovina}

Prvú čast̉ nálezu publikoval $V$. Hanuliak $(2001,189)$ ako umelecky stvárnenú plastiku rukoväte noža vyrobenú zo slonoviny a považoval ju za luxusný import z francúzskeho okruhu rezbárstva. Nakol'ko predmety vyrobené z kostnej kompakty po úprave a vyhladení môžu byt’ po makroskopickej stránke 


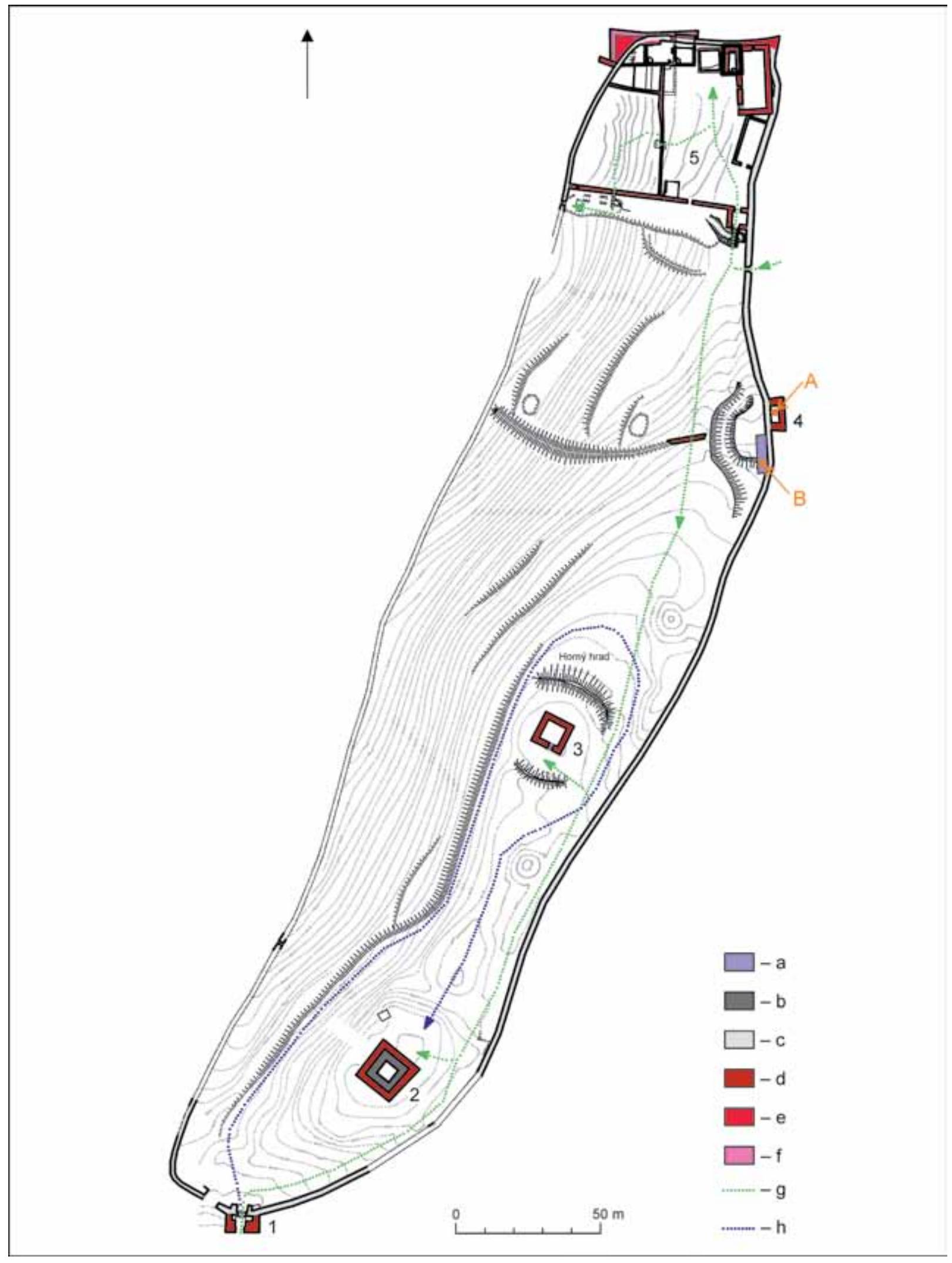

Obr. 2. Zvolen-Pustý hrad, Horný hrad - plán. A - miesto nálezu 1. fragmentu v roku 1996; B - miesto nálezu 2. fragmentu v roku 2019. 1 - vstupná brána; 2 - veža I. (komitátny hrad); 3 - veža II.; 4 - veža (bašta) vo východnej línii opevnenia; 5 - areál tzv. Dončovho hradu. Legenda: a - sonda 4/2019; b - 2. pol. 12 stor.; c - 1. pol. 13 stor.; d - 2. pol. 13 stor.; e - koniec 13. stor.; f - 14. stor.; g - prehliadková trasa; h - pôvodná prístupová cesta. Autor N. Beljak Pažinová. 

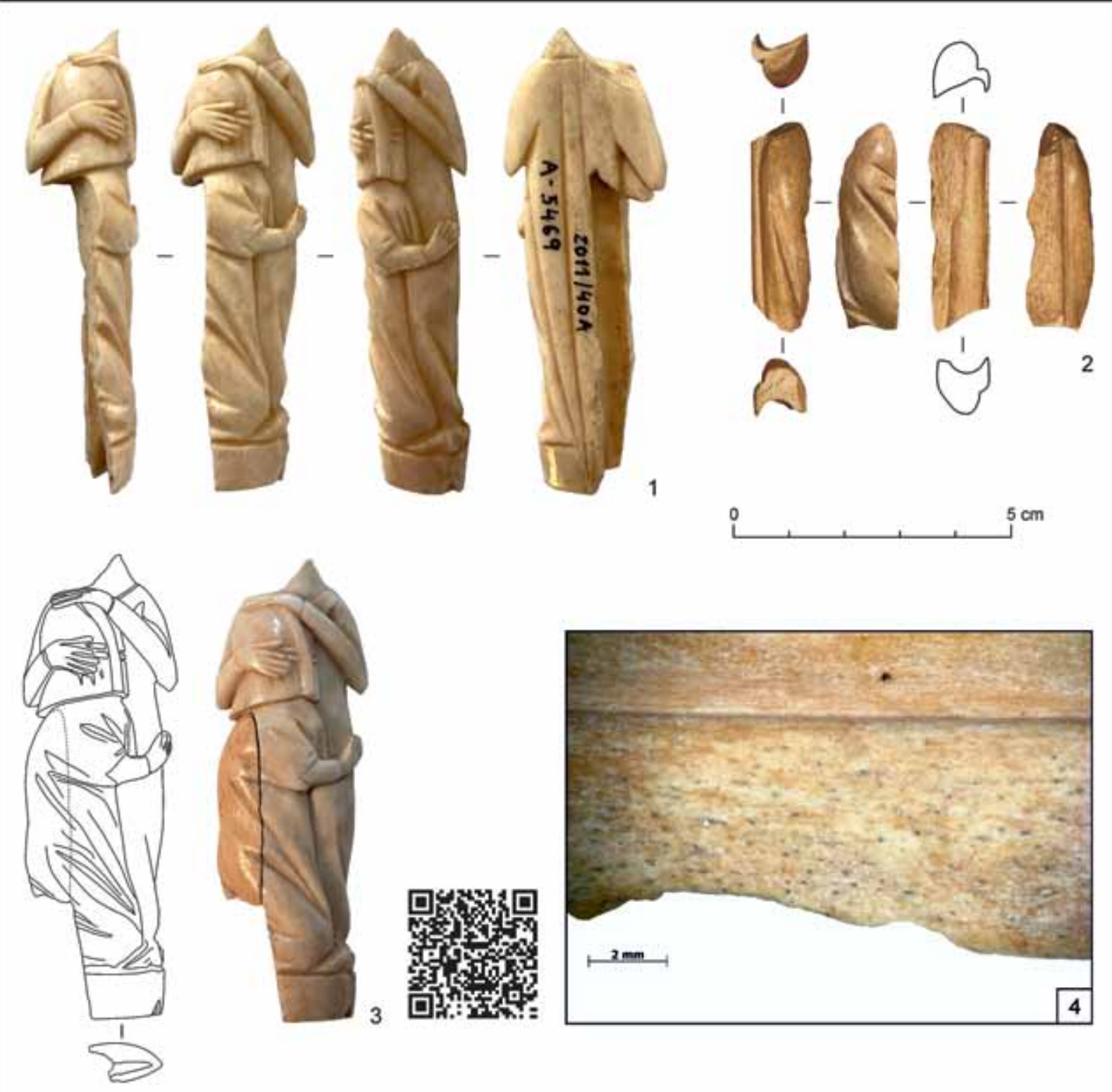

Obr. 3. Zvolen-Pustý hrad, Horný hrad. 1 - plasticky zdobená prvá čast̉ rukoväti objavenej v roku 1996 v interiéri veži vo východnej línii opevnenia; 2 - druhá čast̉ rukoväti objavená v priekope veži (sonda 4) v roku 2019; 3 - spojenie oboch častí rukoväti do jedného celku (foto J. Beljak; kresba M. Čierny) a QR kód na 3D model v programe Sketchfab (autor P.Albert); 4 - snímka štruktúry fragmentu rukoväti (zväčšenie 20 x) objavenej v roku 2019 (prístroj stereoskopická lupa Zeiss Discovery V 12; autor J. Mihályiová).

podobné výrobkom zo slonoviny do takej miery, že častokrát môžu byt’ mylne považované za výrobky zo slonoviny, po náleze druhej časti sme sa preto detailne pozreli na surovinu.

Odlíšeniu predmetov zo slonoviny od tých, ktoré boli vyrobené z kostí a iných materiálov sa venovali napríklad E. O. Espinoza/M. J. Mann (1999), T. Stone (2010) a M. E. Sims/B. W. Baker (2006). Slonovina sa v anglickej literatúre označuje pod názvom „ivory“ a ako poukazujú E. O. Espinoza/M. J. Mann $(1999,5)$ spája sa predovšetkým s označením klov slonov, avšak z chemického hladiska sú kly a zuby cicavcov rovnakého pôvodu.

Najčastejšie sa na vyrezávanie využívali kly slonov a mrožov vzácnejšie aj kly narvala, vorvaňa, hrocha či prasata bradavičnatého (Stone 2010, 1). Makroskopicky pozorovatelné rozdiely medzi jednotlivými druhmi klov resp. slonoviny prehladne charakterizovali E. O. Espinoza/M. J. Mann (1999, 9). 


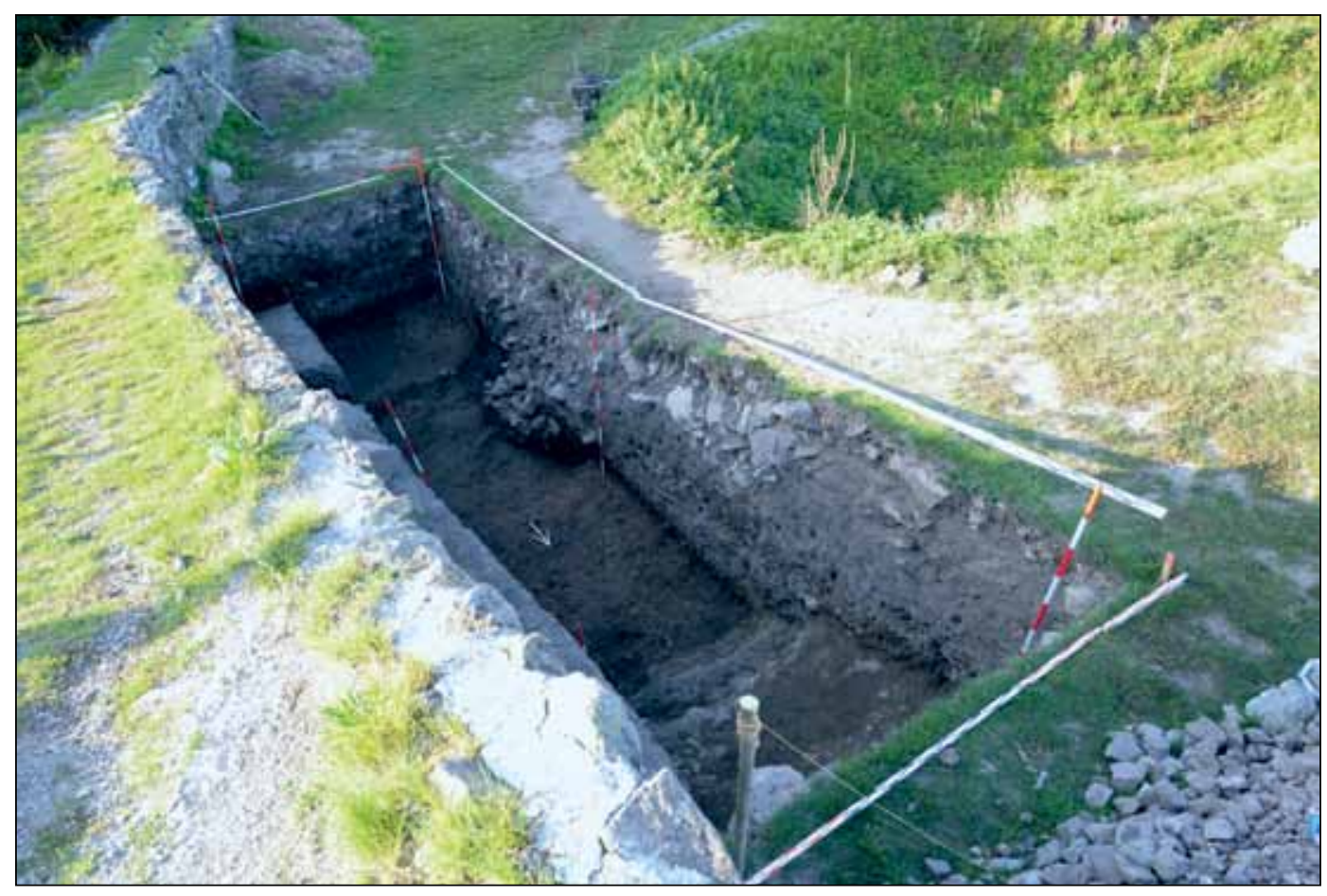

Obr. 4. Zvolen-Pustý hrad, Horný hrad. Sonda 4/2019 pri vnútornom líci východnej línii opevnenia Horného hradu. Autor J. Beljak.

Artefakty vyrobené z klov slona či mamuta sú jedinečné tým, že mávajú na priereze pretínajúce sa vzory, táto charakteristická kresba viditel’ná volným okom, prípadne pod malým zväčšením sa nazýva Schregerove línie (Hornbeck 2015, 113). Schregerove línie sú zaobleného/oválneho tvaru a utvára ich zubný dentín, ktorý tvorí až 95 \% sloních a mamutích klov (Espinoza/Mann 1999, 10). Slonovina má vyššiu zložku mineralizovaného tkaniva ako kost’ a javí sa hladká bez viditelných nepravidelností v textúre (Sims/Baker 2006, 1). Ďalšou odlišnostou slonoviny od kosti je, že slonovina neobsahuje systémy kostnej drene či krvných ciev a je všeobecne tvrdšia, belšia, hustejšia a tažšia ako kost' (Stone 2010, 1). Kost̉ je mineralizované spojovacie tkanivo, ktoré pozostáva $\mathrm{z}$ fosforečnanu vápenatého, proteínov a lipidov (Espinoza/Mann 1999, 22). V prípade kosti sú na jej vyhladenom povrchu viditelné jamky a kanáliky, ktoré sú pozorovatelné, ako jemné tmavé škvrny, škrabance alebo pásiky (Sims/Baker 2006, 1). Štruktúry viditelné na vyhl'adenom povrchu kosti nazývame Haversov systém, pričom spomenuté tmavé štruktúry na povrchu kosti sú Haversove kanáliky, ktorých vzhlad je častokrát zvýraznený organickým materiálom objaveným na stenách jamky (Espinoza/Mann 1999, 22).

Identifikácia suroviny objavenej rukoväte sa uskutočnila podla schém E. O. Espinozy/M. J. Mann (1999) a T. Stone (2010). Taxonomická a anatomická identifikácia kosti, z ktorej bol artefakt vyhotovený, nebola vzhl’adom $\mathrm{k}$ značnému stavu opracovania suroviny s využitím výlučne nedeštruktívnych metód možná. Pri makroskopickej a na ňu nadväzujúcej mikroskopickej analýze novoobjavenej časti (obr. 3: 4) sme zistili, že na povrchu artefaktu nie sú viditelné Schregerove línie a povrch nevykazuje zhodu so štruktúrou dentínu a morfológiou zuboviny zvierat (slona, hrocha, narvala, mroža, vorvaňa). Na povrchu artefaktu sú viditelné tmavé jamky vyplnené organickou hmotou. Detekované útvary sú Haversove kanáliky, ktoré sú súčastou Haversovho systému, čo je základná funkčná jednotka kompaktnej kosti. Revízii sme následne podrobili aj prvú (väčšiu) čast̉ rukoväte, ktorá je vystavená v mestskom múzeu v Starej radnici vo Zvolene. Po získaní povolenia $\mathrm{k}$ jej obhliadnutiu a 3D dokumentácie od Lesníckeho a drevárskeho múzea vo Zvolene sme zistili, že aj v prípade staršieho nálezu sa na jeho povrchu nachádzajú rovnaké útvary a nejde teda o výrobok zo slonoviny, ale z kostnej kompakty (substantia compacta). 


\section{Reliéfny motív}

Na prvý pohlad je v zobrazenej scéne na rukoväti evidentná interakcia dvoch postáv. Jedna z nich (postava 1) klačí pred druhou vzpriamene stojacou postavou (postava 2). Postava 1 je zobrazená v jednoduchom jednoliatom rúchu, s nasadenou helmou na hlave. Je štylizovaná ako klačí na oboch kolenách, pravú ruku má mierne zohnutú, pričom sa dlaňou otvorenej ruky dotýka druhej postavy na boku, v miestach tesne pod pásom. L’avá ruka postavy 1 nie je viditelná. Hlavu má opretú na prsiach vzpriamenej postavy. Nakol'ko je postava vyobrazená v rytierskej helme, je pravdepodobné, že ide o muža. Postava 2 je oblečená v dlhom jednoliatom rúchu. Vo vzpriamenom postoji sa oboma rukami dotýka klačiacej postavy. Pravú ruku má mierne skrčenú, otvorenou dlaňou sa z pravej strany v mieste priezoru helmy dotýka prilby postavy 1 . L'avú ruku má položenú dlaňou na vrchu helmy klačiacej postavy pred ňou. Hlava vzpriamenej postavy sa nedochovala. Ženské pohlavie tejto figúry predpokladáme na základe štíhlej podoby postavy s jemným stvárnením úzkeho drieku, širších bokov, gracilného krku i ramien osoby a v neposlednom rade uhladenosti vzhladu šiat.

Motív na rukoväti bol v minulosti uvádzaný ako scéna pasovania do rytierskeho stavu (Šimkovic/Beljak/ Maliniak 2013, 29, obr. 32). Predpokladalo sa, že dotyk oboch rúk u vzpriamenej postavy 2 (rytier/šlachtic/ panovník/príslušník kléru) na helme klačiacej postavy 1 (rytier) naznačuje pasovanie za rytiera. Po dôkladnej analýze výjavu však z niekol'kých dôvodov môžeme túto interpretáciu považovat' za nesprávnu. Postava 1 má na hlave helmu, čo sa na dobových zobrazeniach pasovania nevyskytuje a zároveň absentujú tri dôležité znaky rytierstva. Meč, opasok a ostrohy boli dôležitým symbolom feudálnej moci pri ceremoniálnom pasovaní do rytierskeho stavu (Koóšová 2004, 36). Na rúčke z Pustého hradu však ani jeden $\mathrm{z}$ uvedených predmetov nie je vyobrazený. $\mathrm{V}$ obrade pasovania mali posvätný význam predovšetkým meč a ostrohy (Koóšová 2004, 31,32), nakol'ko kandidát za rytiera ich najprv pobozkal, potom poklakol a bolo mu požehnané, napokon mu bol opásaný meč a pripnuté ostrohy. Rovnako nie je štandardný vzájomný intímny dotyk osôb pri pasovaní, resp. požehnaní. Aj z tohto dôvodu je pravdepodobnejšia interpretácia zobrazenia ako objímajúceho sa páru, resp. dvojice pri intímnom geste. Postava 1 (rytier?) klačí pred postavou 2 (dáma?), ktorá ho oboma rukami objíma a pritláča si jeho hlavu $\mathrm{k}$ hrudi, zhruba v blízkosti srdca. Klačiaci postoj postavy 1 môže predstavovat' vzdanie úcty, pokory, podriadenosti, odovzdanosti či samotného vrúcneho vztahu. Analogické gesto (klačiaca postava muža pri stojacej žene) nachádzame napríklad na jednej zo štyroch strán slonovinovej rukoväti noža z prírastkovým číslom 61.37 .1 z neznámej lokality. Nález bol odovzdaný do múzea Clermont-Ferrand, Musée d’Art Roger-Quilliot vo Francúzsku pred rokom 1861 a je datovaný do 14. storočia. ${ }^{2}$ Podobnú scénu vidíme aj na slonovinovom stiluse/deliči účesu vo Williams College Museum of Art vo Williamstowne, Massachusetts v Spojených štátoch, ktorý pôvodne pochádza taktiež z Francúzska a je datovaný do prvej polovice 14. storočia (Randall 1993, 178). V oboch prípadoch je scéna interpretovaná ako milenecká, resp. stretnutie zalúbencov.

Z historického hladiska je dôležitý jediný zobrazený prvok výstroja v rámci scény, a to prilba. Ide o celotvárový exemplár hrncového tvaru. Hrncovité prilby sa používali od začiatku 13. storočia (Frey 2007; Williams/Edge 2004; Žákovský/Hošek/Cisár 2012, 91), pričom ich rôzne typy najlepšie zobrazuje Maciejowska biblia z 13. storočia. ${ }^{3}$ Prilba vyobrazená na analyzovanom reliéfe má silne vystužené priezory a evidentný na nej je aj priečny plát, ktorý vedie od vrcholu cez nos smerom k dolnému okraju (obr. 2: 3). Účelom tohto prvku bolo zosilnit oblast' okolo priezorov a prekryt i zosilnit čelný spoj plátov prilby. Obtažnejšie dýchanie $\mathrm{v}$ takejto prilbe bolo riešené dierkami alebo rôzne tvarovanými dekoračnými prierezmi, ktoré sú viditelné aj na zobrazenom exemplári. Sú to tri zvislé prierezy v tvárovej/lícnej časti. Prilba sa zároveň smerom od očných priezorov k vrcholu zužuje. Na prelome 13. a 14. storočia, resp. začiatkom 14. storočia sa hrncové prilby s nevel'kou úpravou vyvinuli na vedrové, ktorých rozdielnost' od hrncových spočivala vo vydutí zaobleného temena, väššej vel'kosti a dosadaní až na rameno bojovníka, teda váha prilby a úder nepriatela sa prenášal mimo temeno hlavy na ramená jej nositel’a (Klučinal Romaňák 1983, 55). Práve s takýmto typom stotožňujeme helmu na zobrazení opísanej rukoväti. Podobné vyobrazenie prilby akú má nasedená postava z objavenej rúčky na Pustom hrade sa nachádza v rámci bojovej scény na liste s názvom Graf Albrecht von Heigerloch v manuskripte Große Heidelberger Liederhandschrift (Codex Manesse) z rokov okolo 1300-1340. ${ }^{4}$

2 Zdroj: http://www.gothicivories.courtauld.ac.uk/images/ivory/C84D2088_ac3a3c84.html

3 Zdroj: The Crusader Bible, MS M. 638, fol. 20v - vyobrazená scéna na strane vpravo dole. https://www.themorgan.org/collection/crusader-bible/40

4 Zdroj: https://doi.org/10.11588/diglit.2222\#0079 


\section{NÁLEZ RUKOVÄTE V ŠIRŠOM KONTEXTE}

Reliéfne zdobená rukovät z Pustého hradu patrí k jedinečným nálezom. Prvá čast', objavená v interiéri veže vo východnej línii opevnenia Horného hradu v roku 1996, bola na základe z rovnakej kultúrnej vrstvy pochádzajúcich nálezov mincí Ladislava IV. (1272-1290) a Albrechta I. (1282-1298) datovaná na rozhranie 13. a 14. storočia (Hanuliak 2001, 189). Druhá čast', objavená v roku 2019 v kultúrnej vrstve zásypu priekopy (sonda 4/2019), poukazuje na analogické datovanie podložené nálezovou situáciou aj dalšími nálezmi (vrátane denára Ladislava IV. Kumánskeho) do záveru 13. storočia, resp. začiatku 14. storočia (určite pred polovicu 14. storočia). Skúmaná situácia v priekope veži (obr. 4) nepochybne súvisí s procesom zániku sídla a nájdené nálezy (vrátane časti rúčky rukoväte) predstavujú hlavne depóniu odpadu obyvatelov hradu, resp. obdobie už po aktívnom využití priekopy.

Analogické exempláre zdobených, resp. umelecky stvárnených rúčok v Európe nie sú časté, pričom najaktuálnejšie je téma spracovaná v Pol'sku (Kowalczyk-Heyman 2010). Vel'kej oblube sa tešili hlavne v priebehu 14. a v začiatkoch 15. storočia (Holčík 1982, 46). Podrobnejšie sa s nimi u nás v minulosti zaoberal M. Slivka $(1984,384,385)$. Spomenieme preto len zopár z nich. Nález z odpadovej jamy (14.-15. storočie) vo Vysokom Mýte v Čechách zobrazuje stojaceho sokoliara s loveckým psom pri nohách a dravým vtákom na pravej ruke (Sommer 1981, 315-318). Vyrobený bol pravdepodobne z hovädzej kosti a na základe celkového spracovania a samotného námetu rezby má blízky vztah s francúzskou produkciou kostených a slonovinových artefaktov 14. storočia (Šmejda 1999, 187-189, obr. 17). To, že práve sokoliari sú častejším námetom rezbárov je evidentné aj na základe nálezov z neskorého 13. a začiatku 14. storočia o. i. z Francúzska, Nemecka, Estónska, Lotyšska (Comte/Gaborit-Chopin 1987; Darkevič 1966, tab. 25 : 6-8, 11; 26: 6; Folke/Holtmann 1993), Pol'ska (Kowalczyk-Heyman 2010) a novšie aj zo švajčiarskeho Zürichu (Wild 2011, 333, obr 4). Iný motív vidíme na náleze z dediny Mstěnice v Čechách, ktorý pochádza zo zásypu vstupnej časti do podzemných priestorov na usadlosti I. Zobrazená je štíhla postava svätca v dlhej suknici a tunike $\mathrm{v}$ adoračnej polohe. Plastika bola dokonca červene polychromovaná a datovaná je do tretej štvrtiny 14. storočia (Nekuda/Nekuda 1997, 89, 90, 97, obr. 153a). Z nášho územia boli publikované dve umelecky stvárnené rukoväte nožov v podobe postáv ženy a muža s korunou na hlave (král a královná?) z výskumu studni v priestoroch Academie Istropolitany v Bratislave (Slivka 1983, 328, obr. 3: 1, 5; 1984, 407, tab. II: 1, 2). U oboch sa predpokladá z dôvodu nižšej kvality, že boli domáceho pôvodu, spolahlivo však boli datované do 14. storočia a podobné exempláre sa produkovali v severnom Nemecku a Francúzsku (Holč́́k 1982, 46, obr. 14; 15). Pravdepodobne rytiera zobrazuje kostená figurálna rukovät (dížka $8 \mathrm{~cm}$, hrúbka 1,3 cm) objavená v záhrade Bückl v mad’arskom Visegrade. Tvár rytiera (?) lemujú dlhé pramene vlasov a oblečený je do plášta s prevísajúcou kapucňou spočívajúcou na jeho pleciach a chrbte. Postava má na drieku opasok a do nej zasunutý meč. Nohy má voči telu a podstave nepomerne malé. Nález je datovaný do druhej tretiny 14. storočia (Marosi/Tóth/Varga 1982, 315, tab. 55: 176). K Pustému hradu vo Zvolene sa najbližšie reliéfne zdobená rukovät zo záveru stredoveku (začiatok 15. storočia) našla v Banskej Štiavnici-Glanzenbergu (Labuda 2016, 67, obr. 23). V jej prípade ide o zvierací motív v podobe sediaceho leva, pričom analogický exemplár je známy z bratislavského podhradia (Polla 1979, 239, obr. 119: 12; Slivka 1983, 328, obr. 3: 4).

Už v minulosti bolo preukázané, že na Pustom hrade vo Zvolene pôsobili kostiarske, resp. univerzálne dielne (Hanuliak 2001, 190), ktoré vyrábali predmety nielen pracovného charakteru pre lokálne použitie. Zobrazený reliéfny motív dvojice postáv na analyzovanej rukoväti svojou vyspelostou a precíznostou však napovedá, že ide o import. Pôvodné určenie suroviny ako slonoviny sme vyvrátili po makroskopickej analýze. Artefakt tak zrejme nepochádzal z vychýrených parížskych dielní vrcholného stredoveku (13.-14. storočie) špecializujúcich sa na luxusné výrobky zo slonoviny (Koechlin 1924), ale vytvorit ho mohli aj francúzske výrobky napodobujúce dielne napr. v Severnom Nemecku (Janssen 1986, 308). O pôsobení špecializovanej dielne $\mathrm{v}$ Uhorsku, ktorá by takéto luxusné predmety vyrábala zatial' vedomost nemáme.

Podla vzoru podobného nálezu z Podzámku v Štetíne, datovaného do 2. polovice 13. storočia (Kowalczyk-Heyman 2010, 279, obr. 5; Stowiński 2014) s čepelou na jednej strane zdobenou medenou tauziou (obr. 5: 1), môžeme predpokladat', že k antropomorfne zdobenej rukoväti patrila aj výnimočná (zdobená) čepel. Predstavit si ju môžeme azda ako čepel' nožíka aký bol objavený v roku 2010 na nádvorí Pustého hradu - Dolného hradu vo Zvolene v blízkosti vstupnej brány (Beljak a i. 2014, 53, 181, obr. 155; tab. 34: 1). Fragment obojstranne zdobenej železnej čepele, na jednej strane radom pozlátených srdiečok a na druhej radom strieborných špiraloidných hákov (obr. 5: 2) možno spolahlivo (nálezová situáciou s mincou Ladislava IV. Kumánskeho) datovat do záveru 13. storočia. 
Samotný zobrazený motív ako aj krehkost a uhladenost' výrobku dávajú tušite, že artefakt bol osobným majetkom príslušníka šlachty, azda vysokopostavenej dámy, ktorej mohol slúžit pri rôznych každodenných činnostiach, počínajúc príborom. Analogické luxusné výrobky (rukoväte) sú považované prevažne za prejav kultúry stolovania hradnej nobility, vylúčená však nie je ani iná privátna funkcia na individuálnu objednávku vyrábaných produktov (Kowalczyk-Heyman 2010, 247, 248, 272).

\section{ZÁVER}

Z Pustého hradu vo Zvolene sme analyzovali jedinečný nález reliéfne zdobenej kostenej rukoväte, ktorej prvá čast’ sa našla na Hornom hrade v interiéri veže vo východnej línii opevnenia hradu v roku 1996 a druhá čast̉ v roku 2019 približne o $20 \mathrm{~m}$ dalej vo výplni priekopy tej-samej veže.

$\mathrm{V}$ rámci mikroskopickej analýzy artefaktu sa nám podarilo prehodnotit' surovinu, z ktorej bol artefakt vyrobený. Rukovät nebola vyrobená zo slonoviny, ako sa dosial' uvádzalo, ale z kompaktnej kosti neidentifikovaného zvierata. Podrobne sme zároveň analyzovali reliéfne zobrazenie na rukoväti a poukázali sme na analogické nálezy z konca stredoveku v Európe. V minulosti sa scéna vyobrazená na rukoväti rytier v prilbe klačiaci pred stojacou, pravdepodobne ženskou postavou, ktorá ho objíma - interpretovaná ako akt pasovania do rytierskeho stavu. To však po dôkladnej analýze výjavu môžeme vylúčit. Absentujú dôležité znaky rytierstva (meč, opasok a ostrohy) a nie je štandardný ani vzájomný dotyk osôb pri pasovaní, resp. požehnaní. Vierohodnejšie je interpretácia zobrazeného motívu ako objímajúceho sa páru, resp. dvojice pri intímnom geste. Zobrazený motív približujúci vrúcny vztah rytiera a dámy na kostenej rukoväti na sklonku stredoveku nemá $\mathrm{v}$ stredoeurópskom priestore zatial' obdoby.

Zo sociálneho hladiska nález vypovedá o bohatej hradnej nobilite, ktorá na hrade pôsobila záverom 13. storočia, resp. začiatkom 14. storočia, a ktorá disponovala luxusnými výrobkami.

Na záver môžeme konštatovat', že objavenie d’alšej časti figurálne zdobenej kostenej rukoväti z Horného Pustého hradu vo Zvolene, po takmer štvrt'storočí (23 rokov) je „malým zázrakom“, ktorý podnietil opätovný záujem o tento výnimočný artefakt a d’alším krokom k poznaniu života šlachty na stredovekom hrade.

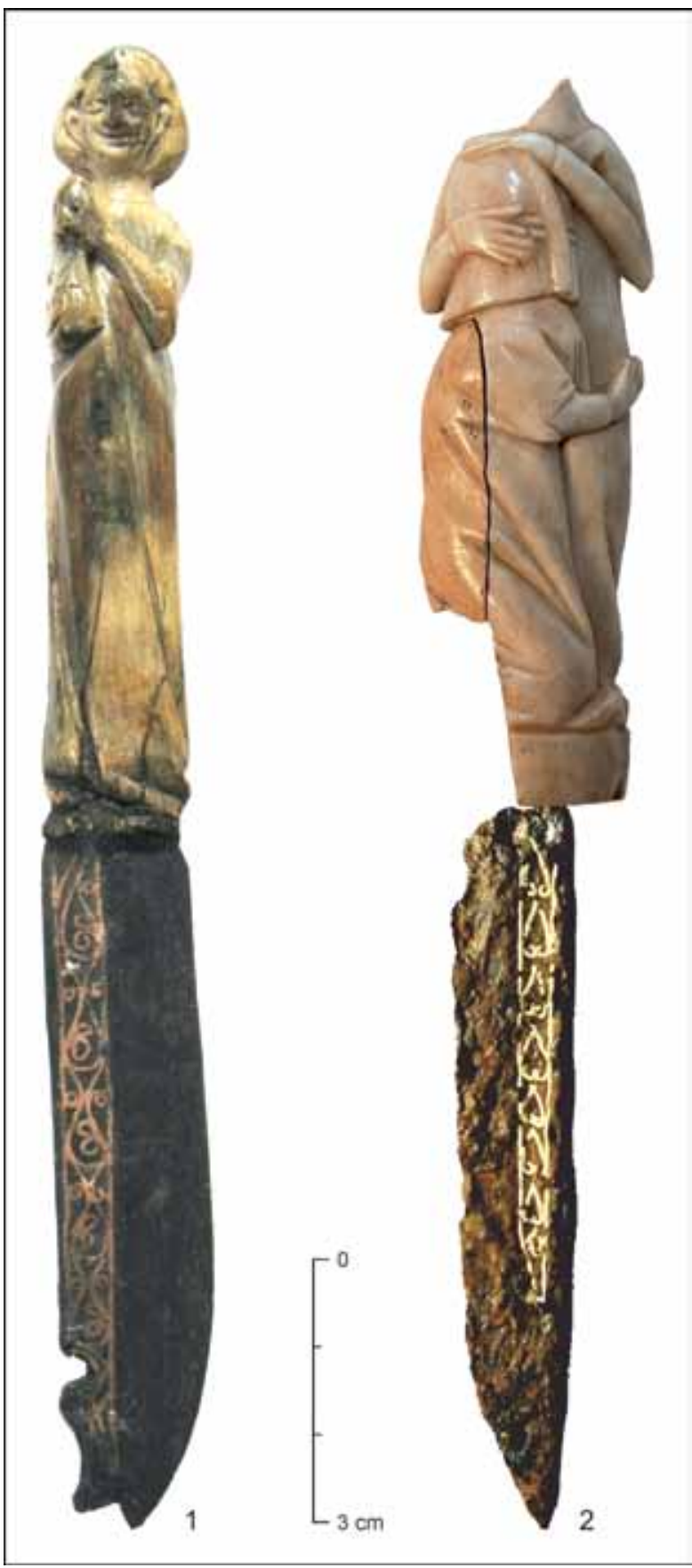

Obr. 5. Zvolen-Pustý hrad, Horný hrad. 1 - reliéfne zdobená rukovät’ zobrazujúca ženu s malým psom a tauziou dekorovaná čepel' z Podzámku v Štetíne, Pol’sko (podl'a Słowiński 2014); 2 - hypotetická rekonštrukcia plasticky zdobenej rukoväte z Pustého hradu - Horného hradu v roku 2010. Foto J. Beljak. so zdobenou čepelou noža z Dolného hradu objaveného 


\section{LITERATÚRA}

Beljak a i. 2014

Beljak/Beljak Pažinová/Šimkovic 2015

Beljak/Beljak Pažinová/Šimkovic 2016

Beljak/Beljak Pažinová/Šimkovic 2018

Beljak/Maliniak/Pažinová 2011

Beljak Pažinová/Beljak 2020

Comte/Gaborit-Chopin 1987

Darkevič 1966

Espinoza/Mann 1999

Folke/Holtmann 1993

Frey 2007

Hanuliak 1999

Hanuliak 2001

Hanuliak 2006

Holčík 1982

Hornbeck 2015

Janssen 1986

Klučina/Romaňák 1983

Koechlin 1924

Koóšová 2004

Kowalczyk-Heyman 2010

Labuda 2016

Marosi/Tóth/Varga 1982

Nekuda/Nekuda 1997

Polla 1979

Randall 1993

Sims/Baker 2006

Slivka 1983
J. Beljak/N. Beljak Pažinová/B. Beláček/M. Golis/J. Hunka/A. Krištín/V. Kohút/ P. Maliniak/M. Mordovin/M. S. Przybyła/D. Repka/M. Slámová/M. Šimkovic/B. Tóth/O. Žaár: Pustý hrad vo Zvolene, Dolný hrad 2009-2014. Nitra 2014.

J. Beljak/N. Beljak Pažinová/M. Šimkovic: Pustý hrad vo Zvolene a opevnenia v jeho okolí. Zvolen 2015.

J. Beljak/N. Beljak Pažinová/M. Šimkovic: Nálezy z cisterny na Pustom hrade vo Zvolene. Pamiatky a múzeá 65, 2016, 7-12.

J. Beljak/N. Beljak Pažinová/M. Šimkovic: Pustý hrad vo Zvolene a hrad Petuša vo svetle aktuálnych výskumov. Zvolen 2018.

J. Beljak/P. Maliniak/N. Pažinová: Zvolenský Pustý hrad vo svetle archeologického bádania (od amaterských výkopov až po začiatok systematického výskumu). Archaeologia historica 36, 2011, 265-278.

N. Beljak Pažinová/J. Beljak: Benefits of the long-term research of the Pustý hrad castle (Deserted castle) in Zvolen and its prospects for the future. Archaeologia historica 45, 2020, 451-466.

F. Comte/D. Gaborit-Chopin: Un gravoir médiéval au Faubourg de l'Evière d'Angers (Maine-et-Loire). Revue Archéologique de l'Ouest 4, 1987, 149-152.

V. P. Darkevič: Proizvedenija zapadnovo chudožestvennovo remesla v vostočnoj Evrope (X-XIV. vv.). Moskva 1966.

E. O. Espinoza/M. J. Mann: Identification Guide for Ivory and Ivory Substitutes. Dexter 1999.

G. Folke/W. Holtmann: Untersuchung zu mittelalterlichen und frühneuzeitlichen Messern dargestellt am Beispiel von archäologischen Funden vornehmlich aus dem weiteren Küstenbereich von Nord- und Ostsee bis zur Mittelgebirgszone. Göttingen 1993.

J. Frey: Neue Erkenntnisse zum älteren Topfhelm von Madeln. Mittelalter. Zeitschrift des Schweizerischen Burgenvereins 12, 2007, 113-120.

V. Hanuliak: Doklady hmotnej kultúry Starého Zvolena (Pustého hradu) od 12. do 17. storočia. Archaeologia historica 24, 1999, 351-361.

V. Hanuliak: Materiálne doklady remeselníckych dielní na Pustom hrade. Archaeologia historica 26, 2001, 185-191.

V. Hanuliak: Vojenské pevnosti Jána Jiskru vo Zvolene. Archaeologia historica 31, 2006, 259-268.

Š. Holčík: Príbory. Bratislava 1982.

S. Hornbeck: Elephant ivory: An overview of changes to its stringent regulation and considerations for its identification. In: E. Hamilton/K. Dodson (ed.): AIC Objects Specialty Group Postprints 22. Washington 2015, 101-122.

W. Janssen: Handwerksbetriebe und Werkstätten in der Stadt um 1200. In: H. Steuer (Hrsg.): Zur Lebensweise in der Stadt um 1200. Zeitschrift für Archäologie des Mittelalters, Beiheft 4. Bonn 1986, 301-378.

P. Klučina/A. Romaňák: Člověk, zbraň a zbroj v obraze doby. I. díl (5.-17. století). Praha 1983.

R. Koechlin: Les Ivoires Gothiques Francais. Paris 1924.

P. Koóšová: Ceremoniál pasovania na rytiera. In: J. Meliš (zost.): Rytierstvo - element v živote stredovekého človeka. Zborník príspevkov z rovnomenného sympózia Trnava, 5.-7. novembra 2004. Trnava 2004, 23-41.

E. Kowalczyk-Heyman: Anthropomorph verzierte mittelalterliche Messergriffe in Polen. Quaestiones Medii Aevi Novae 15, 2010, 241-282.

J. Labuda: Glanzenberg v Banskej Štiavnici. Archeologický výskum zaniknutej lokality. Banská Štiavnica 2016.

E. Marosi/M. Tóth/L. Varga: Müvészet I. Lajos király korában 1342-1382. Katalógus. Székesfehérvár 1982.

R. Nekuda/V. Nekuda: Mstěnice 2. Zaniklá středověká ves. Dům a dvi̊r ve středověké vesnici. Brno 1997.

B. Polla: Bratislava - západné suburbium. Košice 1979.

R. H. Randall: The Golden Age of Ivory: Gothic Ivory Carvings in North American Collections. New York 1993.

M. E. Sims/B. W. Baker: Tusk or Bone? An Example of Fake Walrus Ivory in the Wildlife Trade. Identification Guides for Wildlife Law Enforcement No. 10. Ashland 2006.

M. Slivka: Výrobky z kosti a parohu na Slovensku z obdobia stredoveku. Archaeologia historica 8, 1983, 327-346. 
Slivka 1984

Słowiński 2014

Sommer 1981

Stone 2010

Šimkovic/Beljak/Maliniak 2013

Šmejda 1999

Wild 2011

Williams/Edge 2004

Žákovský/Hošek/Cisár 2012
M. Slivka: Parohová a kostená produkcia na Slovensku v období feudalizmu. Slovenská archeológia 32, 1984, 377-473.

S. Słowiński: Najnowsze znalezisko na Podzamczu w Szczecinie. In: J. Kochanowska (ed.): Trzebiatów - spotkania pomorskie 2013. Trzebiatów 2014, 15-28.

P. Sommer: Střenka ve tvaru sokolníka z Vysokého Mýta. Praehistorica 8. Varia archaeologica $2,1983,315-318$.

T. Stone: Care of Ivory, Bone, Horn and Antler. CCI Notes 6. Ottawa 2010.

M. Šimkovic/J. Beljak/P. Maliniak: Zvolenský Pustý hrad. Sprievodca po hrade. Zvolen 2013.

L. Šmejda: K hmotnej kultúre Vysokého Mýta v stredoveku. Mediaevalia Archaeologica 1, 1999, 169-192.

W. Wild: Nichtkeramische Objekte aus der Nordostschweiz - eine Auswahl. In: U. Niffeler (ed.): Siedlungsbefunde und Fundkomplexe der Zeit zwischen 800 und 1350. Akten des Kolloquiums zur Mittelalterarchäologie in der Schweiz. Basel 2011, 333-340.

A. Williams/D. Edge: Great helms and their development into helmets. Gladius 24, 2004, 123-134.

P. Žákovský/J. Hošek/V. Cisár: A unique finding of great helm from the Dalečín castle in Moravia. Acta Militaria Mediaevalia 8, 2012, 91-125.

\title{
Decorated bone handle from Pustý hrad (Deserted Castle) in Zvolen
}

\author{
Miloš Čierny - Noémi Beljak Pažinová - Ján Beljak
}

Summary

The national cultural monument of Pustý hrad Castle in Zvolen (Fig. 1; 2) stretches over two hilltops of a hill with the same name, which is located on the southwestern edge of the town of Zvolen. Although the castle hill had a strategic position above the confluence of the Hron river and Slatina stream and was a popular settlement place from prehistory, it is mainly known for its high medieval fortification which was built and used by the last Hungarian kings of the Árpád family (Beljak a i. 2014, 36-44; Beljak/Beljak Pažinová/Šimkovic 2015; 2018, 5-63). Archaeological research at the castle has a long tradition (annually since 1992 until now) and has brought a lot of new information on the construction stages of the castle as well as numerous finds which reveal life at the royal residence (for more information see Beljak Pažinovál Beljak 2020; Beljak/Beljak Pažinová/Šimkovic 2015; 2018, 5-63; Hanuliak 1999; 2001; 2006).

The submitted article analyzes the exceptional find of a fragment of a handle made from an animal bone (Fig. 3) with engraved plastic motif from the Upper Pustý hrad castle. The artifact is accompanied by an interesting find context. Its first, larger, part (Fig. 3: 1) was discovered at the Upper Castle in the interior of the flanking tower (the tower in the eastern fortification line) in 1996 (Hanuliak 2001, 189). The second, smaller, part (Fig. 3: 2) was found in the backfill of the moat of the same tower during research season 2019. Match of both artifacts is documented by the proportions, motif engraving as well as the fracture (Fig. 3: 3). Discovery of another part of the figurally decorated bone handle almost a quarter of a century (23 years) later is a "little miracle" which aroused new interest in this exceptional artifact.

In the past, the scene depicted on the handle was interpreted as the act of accolade. This, however, can be excluded after a thorough analysis. Important attributies of knighthood (sword, belt and spurs) are absent and mutual touch at accolade or blessing is not standard either. Interpreting the hugging pair of figures as a couple at an intimate gesture is more acceptable. Figure 1 (the knight) is kneeling before Figure 2 (the lady) who is pressing his head against her chest, near her heart, with both hands. The kneeling position of Figure 1 might express respect, humility, submissiveness, abandonment or a warm relationship. The depicted motif has no analogy in the territory of central Europe. An analogous gesture (a kneeling male figure next to a standing woman) can be found for instance on the ivory knife handle (acc. no. 61.37.1 from an unknow location) from the $14^{\text {th }}$ century in the Musée d'Art Roger-Quilliot in Clermont-Ferrand, France (source: http://www.gothicivories.courtauld.ac.uk/). A similar scene can be seen also on the ivory stilus/hair divider in the Williams College Museum of Art in Williamstown, Massachusetts, USA, which also originally comes from France and is dated to the first half of the $14^{\text {th }}$ century (Randall 1993, 178). In both cases, the scene is interpreted as a love scene or lovers' date. 
From the historical point of view, one depicted element of armour in the scene is important, the helm. According to the bulge of the rounded top, it is a face-covering great helm/bucket helm. Such helms were used at the turn of the $13^{\text {th }}$ and $14^{\text {th }}$ century or in the first decades of the $14^{\text {th }}$ century (see the fighting scene on the page called Graf Albrecht von Heigerloch in the manuscript of Große Heidelberger Liederhandschrift (Codex Manesse) from around 1300-1400 (DOI: https://doi.org/10.11588/diglit.2222\#0079).

The depicted relief motif of the pair of figures with its precocity and preciseness suggests that it is an import. The artifact probably did not come from famous workshops of Paris in the High Middle Ages $\left(13^{\text {th }}-14^{\text {th }}\right.$ century) specializing in luxurious ivory products (Koechlin 1924) as previously assumed (Hanuliak 2001, 189). Macroscopic analysis of both fragments showed that compact bone tissue was used for its production (Fig. 3: 4). Thus, it might have been produced by a workshop imitating French products. Such workshops worked e. g. in northern Germany (Janssen 1986, 308).

The depicted motif itself as well as the brittleness and elegance of the artifact suggest that it was a personal property of a rich lady and she could have used it for various everyday activities, e. g. as a piece of cutlery. Judging by the similar find from Szczecin-Podzamcze dated to the $2^{\text {nd }}$ half of the $13^{\text {th }}$ century (Stowinski 2014), an exceptional (decorated) blade must have belonged to the anthropomorphically decorated handle (Fig. 5).

Dating of the artifact (Fig. 3) on the basis of the analysis of the image and the find situation (cultural layer with coins of Ladislaus IV of Hungary and Albrecht I von Habsburg) corresponds with the turn of the $13^{\text {th }}$ and $14^{\text {th }}$ centuries $(H a-$ nuliak 2001, 189) or can be definitely dated before the mid $14^{\text {th }}$ century.

Fig. 1. Zvolen-Pustý hrad Castle, the Upper Castle. Aerial view of the castle area from the east. A - place of discovery of fragment 1 in 1996; B - place of discovery of fragment 2 in 2019. Legend: a - moat of the tower in the eastern fortification line; b - trench 4/2019. Author: J. Beljak.

Fig. 2. Zvolen-Pustý hrad Castle, the Upper Castle - plan. A - place of discovery of fragment 1 in 1996; B - place of discovery of fragment 2 in 2019. 1 - entrance gate; 2 - tower I (county castle); 3 - tower II; 4 - flanking tower in the eastern fortification line; 5 - area of the so-called Donč's castle. Legend: a - trench $4 / 2019 ; b-2^{\text {nd }}$ half of the $12^{\text {th }}$ century; $\mathrm{c}-1^{\text {st }}$ half of the $13^{\text {th }}$ century; $\mathrm{e}$ - end of the $13^{\text {th }}$ century; $\mathrm{f}-14^{\text {th }}$ century; $\mathrm{g}$ - sightseeing tour; $\mathrm{h}$ - original access road. Author N. Beljak Pažinová.

Fig. 3. Zvolen-Pustý hrad Castle, the Upper Castle. 1 - plastically decorated first part of the handle discovered in 1996 in the interior of the tower in the eastern fortification line; 2 - second part of the handle discovered in the moat of the flanking tower (trench 4) in 2019; 3 - connection of both parts of the handle into one whole (photo by J. Beljak; drawing by M. Čierny) and the QR code for a 3D model in the Sketchfab software (author P. Albert); 4 - photo of the structure of the handle's fragment (twenty fold magnification) discovered in 2019 (stereoscopic magnifier Zeiss Discovery V 12. Author J. Mihályiová.

Fig. 4. Zvolen-Pustý hrad Castle, the Upper Castle. Trench 4/2019 near the interior face of the eastern fortification line of the Upper Castle. Author J. Beljak.

Fig. 5. Zvolen-Pustý hrad Castle, the Upper Castle. 1 - the handle decorated with a relief depicting a woman with a little dog and the inlaid handle from Podzamcze in Szczecin, Poland (after Słowiński 2014); 2 - hypothetical reconstruction of the plastically decorated handle from Pustý hrad-the Upper Castle with the decorated knife blade from the Lower Castle discovered in 2010. Photo by J. Beljak.

Mgr. Miloš Čierny

Archeologický ústav SAV v Nitre

Akademická 2

SK - 94921 Nitra

milos.cierny@savba.sk

PhDr. Ján Beljak, PhD.

Archeologický ústav SAV v Nitre

Akademická 2

SK - 94921 Nitra

jan.beljak@savba.sk prof. PhDr. Noémi Beljak Pažinová, PhD.

Univerzita Konštantína Filozofa v Nitre

Katedra archeológie

Tr. A. Hlinku 1

SK - 94974 Nitra

nbpazinova@ukf.sk 
